\title{
SYMBOLIC CONSUMPTION IN THE CASE OF BRAND COMMUNITIES
}

\author{
SZABOLCS PRÓNAY ${ }^{1}$ - ERZSÉBET HETESI ${ }^{2}$ \\ ${ }^{1}$ Faculty of Economics and Business Administration, University of Szeged \\ E-mail: pronay.szabolcs@eco.u-szeged.hu \\ ${ }^{2}$ Faculty of Economics and Business Administration, University of Szeged
}

The idea of symbolic consumption is based on the assumption that consumption is more than just functional problem solving: products and brands have significant meanings; therefore, they can be utilized as symbols in the cultural ecosystem. However, grasping the meaning of a specific brand can be confusing because it would presume knowledge about the brand as a symbol shared by the customers. We review the contradicting findings in the literature about the symbolic meaning of brands, and we initiate a new reference point in order to dissolve the above mentioned conflict. According to our understanding, the symbolic meaning of a brand shall be examined in the context of specific brand communities and not in general. We suggest that limiting the scope of research to brands with brand communities resolves several limitations of symbolic consumption studies focusing on general issues. Our theoretical model distinguishes the different types of brand communities based on their main cohesive force. In the model, at one end we find image based brand communities where the brand image is the main cohesive force, while at the other end we find brand-subcultures where the members are more committed to each other than to the brand.

Keywords: consumption, consumer behavior, brand community

JEL-code: M31

\section{INTRODUCTION}

Postmodern consumer society has developed new consumption patterns in many respects, allowing further examination of the sociology of consumption. The sociology of consumption deals with the sociological aspects of purchasing, owning, and using products, focusing on the symbolic values of goods. Symbolic consumption is the act when customers buy goods not only for their value in 
function and use, but they intend to communicate a message towards others - or, in many cases, to themselves - through their meaning. However, the basic findings of symbolic consumption can be criticized in several points, as it is difficult to determine the symbolic value of goods, and thus we cannot presume a generally accepted meaning behind the consumption of a particular brand or product in most cases.

In our study, we describe this contradictory nature of symbolic consumption; and in order to resolve the contradictions, instead of studying general consumption acts we focus on a specific consumption area, namely on collective consumption. Nowadays, the concept of group affiliation requires a much broader interpretation, since now we can easily become a member of a group even without personal presence, for instance, through the social media or the act of consumption. In our study, we address the latter phenomenon, i.e. how choosing the same brand can create group awareness and how the consumption of the brand influences group membership. The groups formed along brand choice are called brand communities whose members are linked by their loyalty to the same brand. In our paper, we describe the group-forming nature of consumption and the specific features of brand communities; we also discuss a special case of communal consumption, i.e. brand subcultures. A brand subculture - like micro- and subcultures in general involves the followers of principles divergent from the values and norms of the social macroculture. In this case, it is defined by a cohesive community formed around a particular brand.

In this study, we are aiming to define and model the relationship between brand communities and brand subcultures. While in the former brand is the main cohesive force, in the latter it is belonging to a community. This differentiation at the same time reflects different consumer habits, thus it is useful to apply various practical marketing approaches for these two forms of collective consumption.

\section{THEORETICAL BACKGROUND: COMMUNAL CONSUMPTION AS A PECULIAR INSTANCE OF SYMBOLIC CONSUMPTION}

The sociology of consumption is an emerging discipline, and as such, it raises several problems in definition, conceptualization, research methodology, and measuring. The change in the traditional function of consumption concerns several fields of science, thus besides sociology, other disciplines also apply this new approach in defining and measuring new roles of consumption. Consumption has become a society-forming force in modern society: now we much rather demonstrate our affiliation with consumption, i.e. consumption strengthens status and constructs social identity. 
Consumption means using products, this way performing two functions: on the one hand, they are needed for the visible and stable development of cultural and social categorization; on the other hand, they are tools for creating and maintaining social relationships. In today's society, the main function of consumption is not the satisfaction of individual needs, such as food for eating, but much rather the ability to create emotions (Douglas - Isherwood 1978).

Since the 1980s, we have seen numerous examples of consumption-based approaches in modern social research. Bourdieu emphasizes the central role of the practice of consumption (especially the manifestation of taste) in creating and maintaining dominance and subjection in the course of developing social relationships. He also claims that besides owning material goods, symbolic and cultural capital are important tools of demonstrating social status (Bourdieu 1984).

Fred Hirsch applies a similar approach when he writes about positional goods in analyzing the social barriers of economic growth: in his point of view, in modern societies more and more products become positional products, whose function is not to satisfy needs but to demonstrate social status (Hirsch 1976). However, it has to be noted that postmodern theoreticians had little empirical background; they influenced the development of the sociology of consumption with their suggestive ideas and arguable theories (Campbell 1995).

In the literature, mostly the functional and symbolic dimensions of consumption are touched upon. In the case of functional consumption, the consumer decision can be traced back to rational reasons, the functional usefulness of the product lies behind its purchase as a motivator; while symbolic consumption involves both the purchasing of products whose necessity is difficult to explain and the purchasing of brands whose message the customer would like to identify with, this way expressing their identities (Töröcsik 2011). The basis of symbolic consumption is product symbolism. Based on O'Cass and Frost (2002), product symbolism is what the product or the brand means for customers and the set of emotions which they experience during purchase and use, such as enthusiasm, pride, or pleasure. The symbolic content of the brand is closely connected to the image which is recalled by a certain brand in the customers' minds.

The sociology of consumption has examined symbolic consumption and its motivations in many respects. The idea behind the purchase of products from a symbolic aspect is that we are what we own, since we can consider our material possessions as extended parts of our personality (Belk 1996). These objects embody a meaning system through which we express our personality and communicate with our environment. Therefore, we tend to connect only the goods with a desired meaning to our identity, while we keep away from those with an undesired meaning (Sirgy et al. 2008). 
As the supply of extraordinary consumer goods increases, so does the emphasis on the symbolic content of choices between products with nearly identical functions, highlighting the meaning which belongs to the chosen brand and thus to the customer choosing that particular one (Törócsik 2006). According to the new consumer behavior approach, the customer is not only an automaton who responds to an information input with a brand choice output, aiming to maximize their satisfaction, but can be interpreted as an individual in a social relation, engaging in several cultural interactions. A product such as a car is no longer a mere means of transport but an object of fantasy, pleasure, prestige, strength, pollution, sexuality, mobility, relationship, aggression, and numerous related cultural phenomena (Schouten - McAlexander 1995; Belk 1996). Therefore, as consumption becomes an increasingly dominant part of people's life, scientific research of the new consumer behavior aims at revealing the relation between consumption and other segments of a person's life.

According to Baudrillard $(1981 ; 1998)$, one of the most excellent representatives of postmodern philosophy, in capitalist society products are no longer consumed for their value in use but for the symbolic content which is inseparably related to them. This understanding, being the philosophical basis of symbolic consumption, has found several proponents (Belk 1988; 1996; Cherrier-Murray, 2004); however, it has also served as the basis for many critical opinions (Campbell 1996; Hetesi et al. 2007).

Campbell (1996) claims, for instance, that we can easily come to a contradiction following Baudrillard's $(1981$; 1998) logic: A wedding dress, a children's toy, or a photo album may have an unambiguous meaning only for the owner of the given object, as these things often do not mean anything special for an outside observer. Therefore, he maintains that this kind of meaning cannot be the subject of studies in the sociology of consumption (Campbell 1996). Campbell (1996) limits the scope of symbolic consumption to external symbolism, and excludes from examination the cases of product symbolism where the product carries a meaning not for the environment but merely for the customer.

However, it is important to underline that this double (external and internal) motivation of consumption was present as early as the beginning of economic thoughts. Adam Smith distinguished between the individual's two competing motivations: the motivation of egoism and the motivation of social recognition (Hámori 1998). The author trio of Bell, Holbrook and Solomon (1991) follows the same logic when they distinguish between two dimensions of product symbolism. One of them is esthetic or hedonic value, in the case of which the related emotions are important for customers because of themselves and not because of others, i.e. it is based on internal motivation. The other is social or status granting value, which serves to create desired impressions in the others during the con- 
sumption of certain goods, so it is associated with external motivations. Elliott (1997) also adopts this categorization when he differentiates inward "self-symbolism", forming the customer's self-identity, and outward "social-symbolism", affecting the customer's social environment. These two types of symbolic consumption form and maintain the customer's personality and relationships with the social environment (Kovács 2005; 2007).

Nevertheless, Campbell (1996) not only questioned the existence of internal symbolic consumption, but also expressed doubts regarding external symbolic consumption. He claims that only given circumstances can provide meanings for objects. The message of a product can be interpreted with difficulty if it is meant for a stranger and lacks all circumstances helping interpretation. According to Campbell (1996), we cannot assume a general language for the meaning of products, thus it cannot be decoded unambiguously. McCracken (1986) calls the attention to an even more contradictory phenomenon. Namely, the more an individual considers clothing as a kind of language, the more freely they combine the articles; thereby expressing their personality as fully as possible. However, the message created in this way becomes increasingly uninterpretable and confusing. If we assume that there is an observer who can read a kind of message from the products consumed by an individual, it does not automatically follow that others will read the same message from given signs; moreover, we cannot state that any of the perceived messages correspond with what the individual intended to express (if they actually had any communicational intentions at all). The above listed critical points can be summarized by the claim that sociologists "read consumption backwards", which means that they attribute meanings to certain products without taking the circumstances into consideration. They draw the conclusion that the individual actually wanted to express a message by purchasing them. However, there is no evidence to the fact that the customer wanted to communicate anything with a given product or brand (Campbell 1996).

In general, nowadays the phenomenon of symbolic consumption can be observed in many ways; however, the examination of this phenomenon has quite many limitations from a scientific aspect. In our study, we aim at resolving the above described contradictions in the sociology of consumption, by examining symbolic consumption in a special case, namely in the brand choice of groups. We accept the fact that an outsider may not be able to receive a clear message from a particular consumption, consequently, while studying the phenomenon of symbolic consumption we assume that a certain common interpretation is needed for understanding brand choice as a communication act. This indicates that symbolic consumption can be more clearly observed in the case of collective brand choice; therefore, it can be better examined in this context. 
In our study, we examine a specific form of human relationships, namely the community-forming force of brands. It is a phenomenon which is special in the sense that the experience of belonging to a community and sharing values is formed around a particular brand.

\subsection{The community-forming force of consumption}

Since the 1960s, research on consumption has been given increased impetus by marketing research results, according to which many consumer decisions cannot be predicted based on only socio-economic and demographic characteristics. Branding is a means of communication for marketing specialists, by which they communicate that a brand makes us, customers different; buying and using a brand single us out from the crowd.

However, marketing specialists often disregard the significance of one particular motivating force which is actually the second most dominant for humans after physiological and safety needs: the desire for belonging to a group. In the world of random occurrences, people need a system providing sense and standard.

Customers frequently search for communities where they can feel good, they can identify with shared values, they feel commitment, and where being together itself gives pleasure and experience. These may be religious or political communities, or may be groups in the social media, but they can also be communities forming around brands.

As a result, it is the group that makes the outside world interpretable for the members. Each member is an individual proof of the fact that the system of values represented by the group is to be followed (Atkin 2004). Wattanasuwan (2005) highlights that nowadays group affiliation does not necessitate belonging to an actual social circle, we can become part of certain imaginary groups merely by our consumption. Through the brand of our car, shoes, clothes, and other consumer goods we engage in a community with people who express their similar personality with the help of the same brands.

The desire for engaging in a community with others is still alive in the individual, but they need to choose a new way of this community, i.e. the brand community. A brand community is a specialized, non-geographically bound community, based on a structured set of social relations among admirers of a brand. It is specialized because at its center there is a branded good or service. It has three important cohesive elements: (i) the shared consciousness of belonging; (ii) the sense of moral responsibility, i.e. everybody is willing to make efforts for the community and the members, if not in another way by buying only the given 
brand, this way expressing loyalty; (iii) shared traditions and rituals which are typically related to the common practices of consumption and brand use (Muniz - O'Guinn 2001: 412-413).

Consequently, loyal customers of a given brand form today's "cults". Atkin (2004) presumed this relationship to be so strong that he created the concept of cult-brand as a collective name of brands which an extensive loyal community belongs to. At first, it may seem bold to link religion and brand use in this manner, since most people do not consciously declare themselves a member of any brandcult. However, it can be easily seen that they indeed engage in a community with an imaginary group. One only has to think of the common occurrence when two cars of the same type are waiting next to each other at a traffic light, or several people are taking out mobile phones of exactly the same kind at a meeting. In such situations it is common that the owners survey each other, at the same time creating a positive feeling in the individuals if they discover a similarity also in personality in each other; while it may cause antipathy if they find the other strikingly different. In the former case, they may feel that this brand indeed suits their personality, since the "brand mate" is similar; while in the latter case, they might think that this brand does not suit either the customer or the "brand mate", i.e. they do not fit to the community which this brand belongs to. Nevertheless, we can also think of less common occurrences, when Apple fans camp together in front of the store when a new model is introduced, or when fanatics of Harley Davidson ride the roads in a crowd of hundreds. Consequently, the sense of group membership related to brand use is an existing phenomenon, although besides being loyal to the brand it also requires the customers to recognize group awareness. The question arises: what motivates this kind of community and how this factor affects consumer behavior.

People usually join communities not in order to gain conformity but in order to sustain and extend their individuality (Garai 2003). This is the "paradox of group affiliation", which strengthens individuality by the person accepting the norms of a group (Atkin 2004). By joining a community, the individual separates from the individuals outside the community and becomes the member of a distinct group (Garai 2003). Individuals can collectively express the aspects of their personality which differ from that of the other members of society; moreover, they can collectively take on characteristics and acts which the other members of society would occasionally reject, in other words, group members are similar in terms of being different. As more and more individuals owning a product of the same brand come into contact with each other, so will the motivator supporting the ownership of the given brand be increasingly strong (Ligas Cotte 1999). 
Hámori (1998: 139) describes this phenomenon in a slightly different way by saying that

\begin{abstract}
the value which is possibly the most important for people in joining these cults and movements is safety, which arises from the mere existence of the flock. The choice of others has a positive external effect on the person joining the cult, because certainty, which they need so much, depends on how many people share the common faith. Many, but not too many, followers increase safety. However, a large number of followers is attractive for outsiders only up to a point.
\end{abstract}

The existence of this "point" indicates that group-forming goods - for example cult-brands - have interdependent usefulness, i.e. the usefulness of these goods is related to their social characteristics. It depends on how many people own such a product, i.e. how large the group is (Hámori 1998).

The concept of "club goods" introduced by Buchanan (1965) grasps well this duality which characterizes the attractiveness of a community with a properly large, but not too large, number. If the number of members exceeds a critical point, the perceived value by the club members decreases with every new member, because belonging to a community with too many members no longer means separation from the majority (Hámori 1998; Kovács 2007). If the motivator of a customer's membership of a brand community is that as a member of a community - a club, as it were - they separate from the rest of society, the spread of the given brand can decrease, or even cease this feeling. An example of this is the case of the FUBU brand, which was one of the most well-known hip-hop fashion clothing brands, positioned specifically towards Afro-Americans (the brand name also referred to this: For Us By Us). But as the brand became increasingly popular, wide sections of population started to wear it, so it lost significance in group formation, and eventually the brand moved out of the United States and appeared as a more general fashion brand in Europe.

Drawing on the above discussed points, it is important to note, however, that not every product provides the customer with the sense of belonging to a group, thus it is advisable to limit our examinations to goods which actually fulfill this role. Therefore, we focus our analysis exclusively on those brands which the customer adheres to, i.e. is loyal to. The customers who are loyal to a brand mostly get a sense of group affiliation as well (Belk 1996; Rapaille 2006; McEwen 2005). In what follows, we take a closer look at this sense of belonging to a group, with an aim to support the group-forming nature of loyally consumed goods.

Consequently, brand communities provide a combined sense of joining in and separating. In our research, we examine the different kinds of brand communities and the behavioral patterns the members are to follow in order to legitimize their group membership. 


\section{THEORETICAL MODELLING OF BRAND COMMUNITIES}

In the following, we develop a theoretical model of communal consumption. With the help of this model our aim is to highlight the different nature of brand community types. We can identify two extreme forms of brand communities. At one end, we find simple brand communities that are focused around the brand; at the other end, we find brand subcultures as a distinctive type of communities. In establishing our model, we draw on the conclusion of a literature review.

\subsection{Brand community as an example of the cohesive force of brand loyalty}

One of the most important cohesive forces of a brand community is an identical consumption habit, i.e. loyalty. However, loyalty in this case means not only re-buying but also a close relationship between the brand and its customer. The legitimacy of brand community membership is provided not exclusively by regularly re-purchasing a product of a given brand, but a member is expected to "know" the brand, i.e. its history, system of symbols, etc. In this sense, it can also happen that somebody becomes a member of a brand community, although they do not own a product of the given brand - more precisely, they do not own a typical product of the given brand; for example, they have a Ferrari baseball cap but not a car-, while somebody else who possesses a product of the brand in question cannot become a community member because they do not know the brand well enough, thus they do not behave as expected from a member. It is generally the knowledge of brand history and following the values it represents that differentiate real members from temporal customers (Muniz - O'Guinn 2001).

Brand loyalty also requires considerable sacrifice from the customer; as a result, it has significant alternative costs. However, this strict loyalty is an essential element of every strong community, thus of brand communities, too. Iannaccone (1992) points out the significance of strictness, which is manifested in that these rules make the members' sacrifice inevitable; thereby a cult avoids free riders from joining. Furthermore, he adds that a group can only exclude products whose close substitutes are available for its members. In the case of loyal consumer behavior, it counts as sacrifice if a customer gives up other rival brands, thereby variety, in the long term. They may do so because in turn a close substitute of the excluded goods - namely the chosen brand - is constantly available.

Brand community members are characterized by committed loyalty, but this is simultaneously a critical loyalty. This means that brand community members do not blindly accept the decisions of the owner of a given brand, but they try to control and direct commercial decisions in a direction they consider right 
(Muniz - O'Guinn 2001). This also means that a brand community involves the customers who are the most important for the company from a strategic aspect. Hirschmann (1995) claims that customer defection in general is particularly sore for a company, because quality sensitive customers will leave first - since they do not tolerate the smallest decline in quality -, thereby the company loses its most critical and, at the same time, most active customers first. Nevertheless, a community built around the brand may resolve this problem by keeping quality sensitive customers from defection (for a while); moreover, it also secures a platform to communicate critical opinions, providing important information for the company (Muniz - O'Guinn 2001).

We can conclude that an individual can integrate loyally consumed brands in their personality. By doing so, they engage in a community with those to whom the same brands closely belong. Since they claim to belong to this community, they internalize a new symbolic content in their identity at the same time. Based on his research, Atkin (2004) establishes that an individual's relation to a brand cult depends on how close they relate to the other members of the cult, i.e. not the relation to the brand but the relation to the brand community will dominate. Consequently, the brand around which a dominant brand community is formed has a much greater attractiveness for loyal customers, because not only the brand but also the community built around it represents symbolic usefulness for customers. If the attractiveness of a brand image is exceeded by the attractiveness of the community formed around it, we face a specific case of brand communities: brand subculture.

\subsection{Collective consumption at the highest level: brand subcultures}

A brand subculture (in the literature it is also referred to as "consumer subculture") is a separate group within society whose members separate themselves from the others by collectively consumed goods and brands or collective consumption acts. Members of a brand subculture are identifiable, there is a hierarchical relationship among them; they share unique values and have particular jargons and rituals as forms serving symbolic expression. Brand subcultures can go beyond national, cultural, demographic, status and ethnic barriers, their members can join in a brand subculture irrespective of their previously mentioned characteristics (Schouten - McAlexander 1995).

A brand subculture is a type of brand communities, but it differs from a simple brand community which is merely based on a common brand choice, in its members having closer relationships. Not every brand community can be considered a consumer subculture because the members of a subculture generally use the same 
symbols as the majority, but "turn out" their meaning. On the contrary, an average brand community does not necessarily reject general, symbolic meanings, but embraces and completes them (Muniz - O'Guinn 2001). Canniford (2011) distinguishes brand subcultures from brand communities. The former is characterized by strong interpersonal bonds and sometimes socially deviant behavior, while the latter is centralized around the brand itself. "Brand communities, like subcultures, represent a cohesive and dedicated kind of community, but in this case, rather than a resistant and marginalized form of shared social activity leading to a sense of communal belonging, it is the shared consumption of brands that becomes central to community membership, identity, and consciousness" (Canniford 2011: 61).

A brand subculture has a basically concentric structure. The hard-core is the center of the subculture. It includes the most determined and most committed followers, who perform an opinion leader role. Their behavior and opinions represent the pattern which is followed by several - less committed - members. The next circle constitutes of the soft-core, who are less committed, however, still important members and participants of the brand subculture. The members of the hard-core usually have a controlling influence on the members of the soft-core. Outside the soft-core there are the pretenders, who are fond of the brand subculture and adopt some of its elements, but they are not characterized by considerable commitment (Schouten - McAlexander 1995).

Schouten and McAlexander (1995) applied participant observation to explore the life of one of the most well-known brand subcultures, the Harley Davidson motorcyclists. During their research they lived and rode with Harley Davidson crews for a long time, so they directly explored their characteristics. In the subculture of Harley riders, internal separations existing in most brand subcultures are present in a spectacular way. In accordance with what has been discussed, we can see that this separation is hierarchical. The place in the hierarchy of the subculture is collectively determined by several factors, such as age (principle of seniority), participation and leadership in collective activities, riding skills, and Harley-specific knowledge. These and other similar factors, i.e. in general the commitment to the group and its values, determine status. This commitment is made clearly perceptible for others by visible elements (tattoos, special outfit, unique motorcycle exterior), thus they create a kind of special status symbol system. The hierarchy is reflected in the order of riding, where the leader leads the way, followed by the hard-core, then the soft-core, and finally the ones at the bottom of the hierarchy are at the back (Schouten - McAlexander 1995).

Cova (1997) mentions another special type of communal consumption, i.e. "consumer tribes" as a social bond that connects the users of the product or brand. Consumer tribes are less dominant in the consumer's life, and they are 
more transient and require less commitment from the members. "The concept of consumer tribes offers a means to describe communities that do not fit neatly into subcultural or brand community categories" (Canniford 2011: 65). Since close bonds, committed loyalty, shared belief, and knowledge about the brand are in the center of our understanding of brand communities, in our theoretical model, we do not deal with consumer tribes.

\subsection{Theoretical model}

Based on the above detailed literature review, we have developed a theoretical model which identifies the different types of communal consumption. In our model, at one end we find brand based communities, where the brand and its image are the main cohesive force; while at the other end we find brand-subcultures (or brand-cults), where the members are more committed to each other than towards the brand. In our understanding, in the case of brand subcultures the role of the community is more significant than that of the brand, while in the case of simple brand communities it is the reverse. Most of the real life brand communities are situated somewhere in between these two extreme ends (Figure 1).

Figure 1 demonstrates that in the case of brand subcultures the attractiveness of the community is dominant. This leads to the other specific feature of brand subcultures: while a simple brand community is typically formed by individuals in a horizontal relationship, within a brand subculture hierarchical relations prevail.

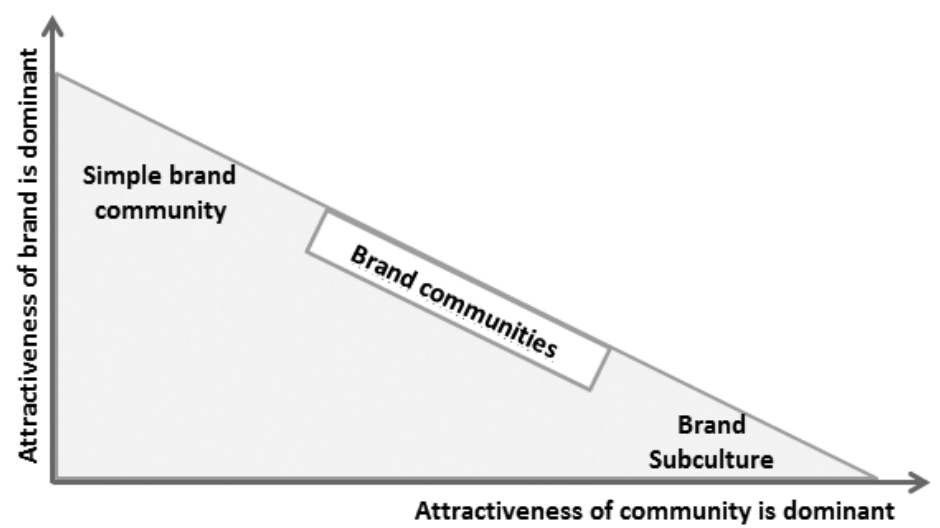

Figure 1. The differences between the two extremes of brand community

Source: authors. 
A further feature of a brand subculture is that it does not search for new members. New members have to make efforts in order to gain acceptance. Potential new members first receive the status of an expectant, and it is only after a while that they can become true members, provided they prove their commitment. In this sense, becoming a member is the result of a kind of socialization, during which the commitment to a brand subculture leads to the internalization of the values of that particular subculture. The general entry barrier is the ownership of the product itself; however, the purchase of the brand in itself does not provide membership - commitment to the community and sacrifice are essential for gaining acceptance.

After discussing the specific features of brand subcultures, it is worth noting that most brand communities are not clear "simple brand communities" or "brand subcultures", but they lie somewhere between the two extremes. We used some well-known brands as illustrators of the different types of communal consumption (Figure 2). It is important to note that by taking these brands as examples our aim is to demonstrate the different types of brand communities; consequently, deeper analysis of the brands in question is not our intention.

Figure 2 demonstrates that a simple brand community (e.g. Nokia) is mostly held together by the brand and the belief in its value, but it is not characterized by a hierarchical structure or particular group cohesiveness. Another example is Apple, where the customers still adhere to the brand, but they have a larger effect on each other and a more intensive interaction between each other. In the case of the already mentioned brand of FUBU - especially earlier when it was

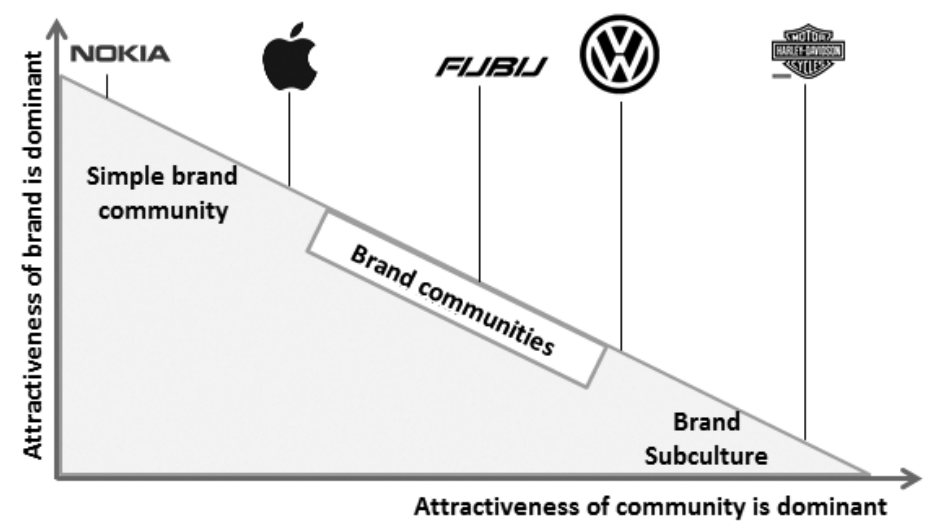

Figure 2. Examples of brand community types

Source: authors. 
specifically a brand of Afro-Americans -, in its being organized around hip-hop culture, the role of the community is already present in the development of brand adherence. As a result, the symbolic meaning of the brand derives from the existence of the community to a greater extent than from brand image. VW Beetle is a product which represents one of the most characteristic cars ever made. Nearly a cult has built around the product; its owners organize national and international brand meetings, and these obsessed customers have a much larger effect on each other than the brand image. At the end of the scale, we find the already discussed example of Harley Davidson, where the brand is still important, as a matter of course, but there is an independent subculture formed around the brand, where the community itself has the largest influence on the members.

\section{CONCLUSION}

Symbolic consumption is an important and popular field of consumer behavior studies. However, we share the skeptical thoughts of some scholars in the field in highlighting the fact that giving a symbolic meaning to a brand is a complex procedure. No matter how hard brand managers try to position their brand, it is impossible to connect an exact and generally accepted meaning to it. Symbolic consumption has an overall personal and subjective nature and presumes a shared understanding of the meaning of the brand among the consumers.

Our aim with this paper was twofold. Firstly, we applied a narrower and more appropriate context for the examination of symbolic consumption, the context of communal consumption, where the above mentioned criterion, i.e. shared understanding, is met. Secondly, we aimed to demonstrate the diverse nature of communal consumption varying from simple brand communities to brand subcultures. According to our understanding, all of these specific types of communal consumption provide appropriate contexts for examining the nature of brand symbolism. However, we do not claim that symbolic consumption can only be detected in communal consumption but rather suggest that brand communities are good examples of this phenomenon providing a better starting point for research than average consumption.

As a managerial implication we can conclude that, on the one hand, a brand community can serve as an attractive factor for customers; on the other hand, the type of this community determines the approach a firm shall apply towards the brand. Simple brand community members are open for centralized brand communication, eager for information about the brand and open for innovations, while brand subcultures follow their own norms and rituals and consider the company - the owner of the brand - more a "slave" than a "master". Brand 
managers shall clearly identify the type of their brand community and set their goals accordingly.

Unfolding the dilemmas of brand communities, several further questions are raised. When and due to what influence do simple brand communities become brand subcultures? Around what brands and along what values are value communities formed? Why does a certain brand become a fetish and why does not the other? What role can marketing play in that a given brand creates value communities? Who achieves and how that cults are formed around brands? How one becomes interested in this? What kind of influence such a brand subculture - cult - may have in the development of a given brand? How can a brand community in a later phase control branding, and how does it affect the organization itself?

\section{REFERENCES}

Atkin, D. (2004): The Culting of Brands. New York: Portfolio.

Baudrillard, J. (1981): Towards a Critique of the Political Economy of the Sign. St. Louis: Telos Press.

Baudrillard, J. (1998): The Consumer Society: Myths and Structures. London: Sage Publications

Belk, R. W. (1988): Possessions and the Extended Self. Journal of Consumer Research 15(2): 139-168.

Belk, R. W. (1996): Studies in the New Consumer Behaviour. In: Miller, D. (ed): Acknowledging Consumption. New York: Routledge.

Bell, S. S. - Holbrook, M. B. - Solomon, M. R. (1991): Combining Esthetic and Social Value to Explain Preferences for Product Styles with the Incorporation of Personality and Enseble Effects. Journal of Social Behavior and Personality 6(6): 243-274.

Bourdieu, P. (1984): Distinction: A Social Critique of the Judgement of Taste. Cambridge, MA: Harvard University Press.

Buchanan, J. M. (1965): An Economic Theory of Clubs. Economica 32(125): 1-14.

Campbell, C. (1996): The Sociology of Consumption. In: Miller D. (ed): Acknowledging consumption. New York: Routledge.

Canniford, R. (2011): A typology of consumption communities, in: Belk R. W. - Grayson K. Muniz A. - Schau H. J. (eds): Research in Consumer Behavior, Volume 13. Bingley: Emerald Group Publishing.

Cherrier, H. - Murray, J. B. (2004): The Sociology of Consumption: The Hidden Facet of Marketing. Journal of Marketing Management 20(5-6): 509-525.

Cova, B. (1997): Community and consumption: Towards a definition of the "linking value" of products and services. European Journal of Marketing 31(3/4): 297-316.

Douglas, M. - Isherwood, B. (1978): The World of Goods: Towards an Anthropology of Consumption. London: Allen Lane.

Elliott, R. (1997): Existentional Consumption and Irrational Desire. European Journal of Marketing 31(3-4): 285-296.

Garai, L. (2003): Identitásgazdaságtan (Economics of Identity). Budapest: TAS Press.

Hámori, B. (1998): Érzelemgazdaságtan (Economics of feelings). Budapest: Kossuth Press. 
Hetesi E. - Andics J. - Veres Z. (2007): Az életstílus kutatási eredmények fogyasztásszociológiai interpretációs dilemmái (Dilemmas in interpreting results of lifestyle research in consumer sociology). Szociológiai Szemle 17(3-4): 115-134.

Hirsch, F. (1976): Social Limits to Growth. Cambridge, MA: Harvard University Press.

Hirschman, A. O. (1970/1995): Exit, Voice and Loyalty, Budapest: Osiris Press.

Iannaccone, L. R. (1992): Sacrifice and Stigma: Reducing Free-Riding in Cults, Communes, and Other Collectives. Journal of Political Economy 100(2): 271-291.

Kovács, K. (2005): Divattermékek és divatmárkák, mint a szimbolikus fogyasztás eszközei. (Fashion Products and Fashion Brands as Means of Symbolic Brand Consumption) Marketing \& Menedzsment, 39(4-5): 72-82.

Kovács, K. (2007): A divattermékek fogyasztása, és a divatterjedés racionális és emocionális mozgatói. (Rational and Emotional Drivers of Fashion Product Consumption and Fashion Spread). Doctoral Thesis, University of Pécs, Hungary.

Ligas, M. - Cotte, J. (1999): The Process of negotiating Brand Meaning: A Symbolic Interactionist Perspective. Advances in Consumer Research 26: 609-614.

McCracken, G. (1986): Culture and Consumption: A theoretical Account of the Structure and Movement of the Cultural Meaning of Consumer Goods. Journal of Consumer Research 13(6): 71-84.

McEwen, W. J. (2005): Married to the Brand. New York: Gallup Press.

Muniz, A. - O'Guinn, T. (2001): Brand Community. Journal of Consumer Research 27(4): 412432.

O'Cass, A. - Frost, H. (2002): Status Brands: Examining the Effects of Non-Product Related Brand Associations on Status and Conspicuous Consumption. Journal of Product \& Brand Management 11(2): 67-88.

Rapaille, C. (2006): The Culture Code. New York: Broadway Books.

Schouten, J. W. - McAlexander, J. H. (1995): Subcultures of Consumption: An Ethnography of the New Bikers. Journal of Consumer Research 22(3): 43-61.

Sirgy, M. J. - Lee, D-J. - Johar, J. S. - Tidwell, J. (2008): Effect of Self Congruity with Sponsorship on Brand Loyalty. Journal of Business Research 61(10): 1091-1097.

Töröcsik, M. (2006): Fogyasztói magatartás trendek (Consumer Behavior Trends). Budapest: Akadémiai Kiadó.

Töröcsik, M. (2011): Fogyasztói magatartás - Insight, trendek, vásárlók (Consumer Behavior, Insight, Trends, Consumers). Budapest: Akadémiai Kiadó.

Wattanasuwan, K. (2005): The Self and Symbolic Consumption. The Journal of American Academy of Business 6(1) 179-184. 